\title{
The Effect of Electrolyte on Dye Sensitized Solar Cells Using Natural Dye from Mango (M. indica L.) Leaf as Sensitizer
}

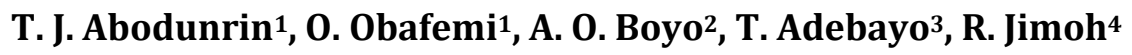 \\ ${ }^{1}$ Department of Physics, Covenant University, Ota, Nigeria \\ ${ }^{2}$ Department of Physics, Lagos State University, Ojo, Nigeria \\ ${ }^{3}$ Chemical Science Department, Redeemers University, Ede, Nigeria \\ ${ }^{4}$ Instrumentation Department, Kwara State University, Molete, Nigeria \\ Email: Temitope.Abodunrin@covenantuniversity.edu.ng
}

Received 31 March 2015; accepted 12 June 2015; published 16 June 2015

Copyright (C) 2015 by authors and Scientific Research Publishing Inc.

This work is licensed under the Creative Commons Attribution International License (CC BY). http://creativecommons.org/licenses/by/4.0/

(c) (i) Open Access

\section{Abstract}

Dye-sensitized solar cells (DSSC) were fabricated with mango leaf dye extracts as natural dye sensitizers at $\mathrm{pH}$ value of 5.20 and temperature of $18.1^{\circ} \mathrm{C}$. Methanol was used as dye-extracting solvent. DSSCs from dye extract of $M$. indica $\mathrm{L}$. with $\mathrm{KMnO}_{4}$ electrolyte had the highest photocurrent density of $1.3 \mathrm{~mA} / \mathrm{cm}^{2}$ and fill factor FF of 0.46 for the sun at its peak. Potassium permanganate $\left(\mathrm{KMnO}_{4}\right)$ had a photocurrent density of $1.3 \mathrm{~mA} / \mathrm{cm}^{2}$ and $\mathrm{FF}$ of 0.8 at sundown. Potassium Iodide (KI), Potassium Bromide (KBr) and Mercury Chloride $\left(\mathrm{HgCl}_{2}\right)$ electrolytes had $0.2 \mathrm{~mA} / \mathrm{cm}^{2}, 0.08$ $\mathrm{mA} / \mathrm{cm}^{2}$ and $0.02 \mathrm{~mA} / \mathrm{cm}^{2}$ photocurrent densities respectively. The fill factors of $0.09,0.03$ and 0.003 respectively for sun overhead while $0.08 \mathrm{~mA} / \mathrm{cm}^{2}, 0.01 \mathrm{~mA} / \mathrm{cm}^{2}$ and $0.01 \mathrm{~mA} / \mathrm{cm}^{2}$ were the values of photocurrent densities respectively at sundown. The fill factors were $0.02,0.0006$ and 0.003 respectively at sundown. The maximum power $P_{\max }$ of the DSSCs were $0.5 \mathrm{~mW} / \mathrm{cm}^{2}, 0.10$ $\mathrm{mW} / \mathrm{cm}^{2}, 0.01 \mathrm{~mW} / \mathrm{cm}^{2}$ and $0.012 \mathrm{~mW} / \mathrm{cm}^{2}$ respectively at $1300 \mathrm{~h}$ at $1630 \mathrm{~h} 0.9 \mathrm{~mW} / \mathrm{cm}^{2}, 0.14$ $\mathrm{mW} / \mathrm{cm}^{2}, 0.005 \mathrm{~mW} / \mathrm{cm}^{2}$ and $0.0015 \mathrm{~mW} / \mathrm{cm}^{2}$ respectively.

\section{Keywords}

Dye-Sensitized Solar Cells, Dye Sensitizer, Electrolytes, M. indica L., Photocurrent Density, Fill Factor

\section{Introduction}

Solar energy remains a foremost energy resource with unlimited capacity to solve man’s numerous energy chal-

How to cite this paper: Abodunrin, T.J., Obafemi, O., Boyo, A.O., Adebayo, T. and Jimoh, R. (2015) The Effect of Electrolyte on Dye Sensitized Solar Cells Using Natural Dye from Mango (M. indica L.) Leaf as Sensitizer. Advances in Materials Physics and Chemistry, 5, 205-213. http://dx.doi.org/10.4236/ampc.2015.56021 
lenges. Dye-sensitized solar cell (DSSC) discovered by Grätzel et al. [1] [2] has gained prominence because of its considerable low cost of production [2], no greenhouse gas emission, eco-friendliness and sustainability. Dye sensitizers perform a primary role of trapping solar energy and converting it to electricity through potential difference that exists between solar cell layers. Quality is a measure of efficiency and fill factor [3].

Anthocyanin, flavonoids from natural sources has been used as sensitizers in DSSCs and recorded low solar energy efficiency conversion [2] [4]-[6]. DSSCs change cheap energy from the sun to electricity established upon different sensitivities in band gap of dye sensitizers and electrolytes [7]. This process involves several subsystems whose work in cycle is in conjunction with the surface of adsorption of the dye deposited on a semiconductor surface that receives near IR photons and visible region of light. It pumps these incident electrons into the conduction band of the semiconductor. Performance of the DSSC is based on the band gap of materials like $\mathrm{TiO}_{2}$, electrolytes and the dye sensitizer. $\mathrm{TiO}_{2}$ is ideal because it has ability to withstand constant electron transfer under solar illumination in the ultraviolet range. Dye absorption performance on $\mathrm{TiO}_{2}$ surface determines efficiency of DSSC [7]. DSSC efficiency of $10.4 \%$ has been observed for use of nanocrystalline $\mathrm{TiO}_{2}$ films [8]. Ruthenium dye photosensitizers are one of the most efficient produced from heavy transition metallic compound, ruthenium polypyridyl complex widely used for its high charge-transfer absorption in the visible spectrum of light; long span of excitation time, good absorption, and high efficiency of metal-ligand charge transfer [9]. Ruthenium complexes are very difficult to make and costly, this limits their applications on large scale in solar cells, encouraging a search for suitable alternatives like organic dyes. However, organic dyes of higher absorption coefficients with similar characteristics and efficiencies up to 9\% have been observed [9]-[11]. Higher absorption in organic dyes could mean thinner nanostructured metal oxide films that is most suitable for use of higher viscous materials and charge transport. Such materials include ionic liquids, solid electrolytes or hole conductors [12].

Leaves of most plants are rich in chlorophyll and its application as natural dye sensitizer has been experimented in many associated studies [3] [4] [13]. Anthraquinones are natural compounds that have medicinal properties as well as give colour pigments to plants [14].

Mango (M. indica L.) is a fairly large genus of Anacardiaceae family of evergreen trees [15]. It grows from 10 to 45 metres height, with a heavy dome-shaped crown and, a stout straight bole, thick bark, dark grey, rough, flaking off when old, with leaves linear, elliptic lanceolate or oblong, 10 - $30 \mathrm{~cm}$ long and 2 - $9 \mathrm{~cm}$ wide giving off an aromatic, resinous odour when crushed.

Anthraquinones and flavonoids from $M$. indica L. are composed of lupeol and certain tannins and saponnins pigments characteristic of Anacardiaceae family. They absorb visible radiation over a range $412 \mathrm{~nm}-664 \mathrm{~nm}$. Solar energy conversion efficiency a function of $\mathrm{J}_{\mathrm{sc}}$, open circuit voltage $\mathrm{V}_{\mathrm{oc}}$, and fill factor FF [17], suggest that their improvement is essential to increasing the conversion efficiency. Mangifera has several active triterpenoids [15] which have several medicinal benefits.

Lupeol's chemical structure is shown in Figure 1 [16]; it contains functional carboxylic group which articulates with the $\mathrm{TiO}_{2}$ surface bonding. In this paper, anthraquinone (Table 1 ) and flavonoid extracts of Mango (M. indica L.) mixed with iodine and four different electrolytes were used as natural dyes sensitizers in the preparation of DSSCs.

\section{Experimental}

The $M$. indica L. leaf pigments were extracted by crushing $317 \mathrm{~g}$ of $M$. indica $\mathrm{L}$. in a milling machine and soaking it in $8000 \mathrm{ml}$ of methanol. This mixture was filtered and a rotary evaporator used to recover the pigment from the mother liquor-methanol. The raw extracts of $M$. indica L. was divided into four and used as dye sensitizer at four different pHs. Two drops of Iodine $(0.1 \mathrm{M})$ solution was added to all the samples then, two drops of $\mathrm{HgCl}_{2}$ was added to a first sample of dye extract, a $\mathrm{pH}$ of 2.16 was recorded at $22.7^{\circ} \mathrm{C}$, two drops of $\mathrm{KBr}$ was added to a second sample, a pH of 1.78 was observed at $22.7^{\circ} \mathrm{C}$, a few drops of $\mathrm{KI}$ added to a third sample had a $\mathrm{pH}$ of $2.25^{\circ} \mathrm{C}$ at $22.6^{\circ} \mathrm{C}$ and lastly two drops of $\mathrm{KMnO}_{4}$ was added to a fourth sample, a pH of 2.58 was recorded at $22.5^{\circ} \mathrm{C}$.

The transparent fluorine-doped tin oxide (FTO) conducting glass had the following dimensions $50 \mathrm{~mm} \times 50$ $\mathrm{mm} \times 22 \mathrm{~mm}\left(\right.$ ALDRICH) having surface resistivity of $7 \Omega / \mathrm{m}^{2}$. The active area of DSSC was $0.54 \mathrm{~cm}^{2}$. The $\mathrm{TiO}_{2}$ paste was prepared by pounding $12 \mathrm{~g}$ of commercial $\mathrm{TiO}_{2}$ (Assay) with $20 \mathrm{ml}$ of concentrated nitric acid. The mixture was well blended and squeegee was used to screen-print the resulting $\mathrm{TiO}_{2}$ paste onto the conduct- 


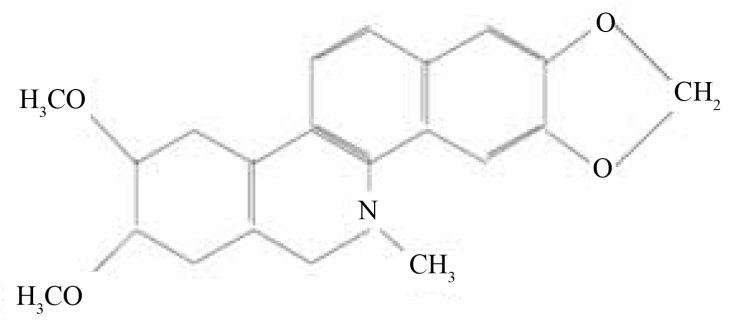

(a)

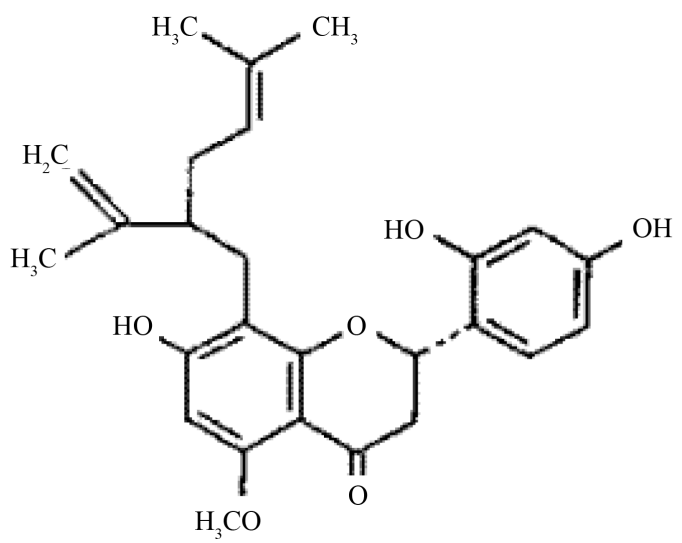

(b)

Figure 1. Chemical structure of two allotropes of $P$. macrophylla. (a) http://journal.9med.net/upload/Image/4QT23.jpg at 21/03/15; 3:48 p.m. (b) http://www.plant-expert.com/upload/structures/34981-26-5.gif 21/03/15 by 3:50 p.m.

Table 1. Phytochemichemical analysis of P. macrophylla.

\begin{tabular}{ccc} 
& Anthraquinones & Flavonoids \\
\hline & ++ & ++ \\
\hline++ & ++ \\
&
\end{tabular}

ing FTO. It was left for 30 min to allow the paste settle and even out the irregularities at the surface, then allowed to dry. Appropriate thickness of the $\mathrm{TiO}_{2}$ working electrode is $9 \mu \mathrm{m}$. It was sintered at $450^{\circ} \mathrm{C}$ for $45 \mathrm{~min}$ to enhance its absorption performance. Then the sintered thin film of $\mathrm{TiO}_{2}$ was immersed $24 \mathrm{~h}$ in the $M$. indica $\mathrm{L}$. prepared, thus allowing the dye pigment to be adsorbed on the $\mathrm{TiO}_{2}$ nanoparticles surface. Glass insulation spacers were stuck on the edges of the base plate of conductive glass at the bottom. This space allows injection of the electrolyte. After cleaning the DSSCs photoelectrode, it is ready for testing.

\section{Characterization}

The absorption spectra of the $M$. indica L. dye was determined with Genesys 10 UV Scanning spectrophotometer an RC, 229,847 series model. Manufactured by Thermo Electron Corporation in USA. Aspex 3020 scanning electron microscope (SEM) was used at different magnification for specific wavelengths under the irradiation of $100 \mathrm{~mW} \cdot \mathrm{cm}^{-2}$. The current-voltage curves were recorded using a multimeter.

\section{Results and Discussion}

The FTIR image of hexane faction (Figure 2) of $M$. indica L. leaf extracts shows all the organic compounds present in the dye (Table 2). Figure 3 shows the optical absorption spectra of $M$. indica L. leaf extracts for $\mathrm{pH}$ 2.16, $\mathrm{pH}$ 1.78, $\mathrm{pH} 2.25$ and $\mathrm{pH}$ 2.58. Absorption spectra of a dye represents the probability of its transition between the ground state, excited state and the incident wavelength range of solar energy absorbed by the dye. All four dyes extract show absorption peaks centered at 303 and $350 \mathrm{~nm}$ in UV-range, with maximum peak at 350 


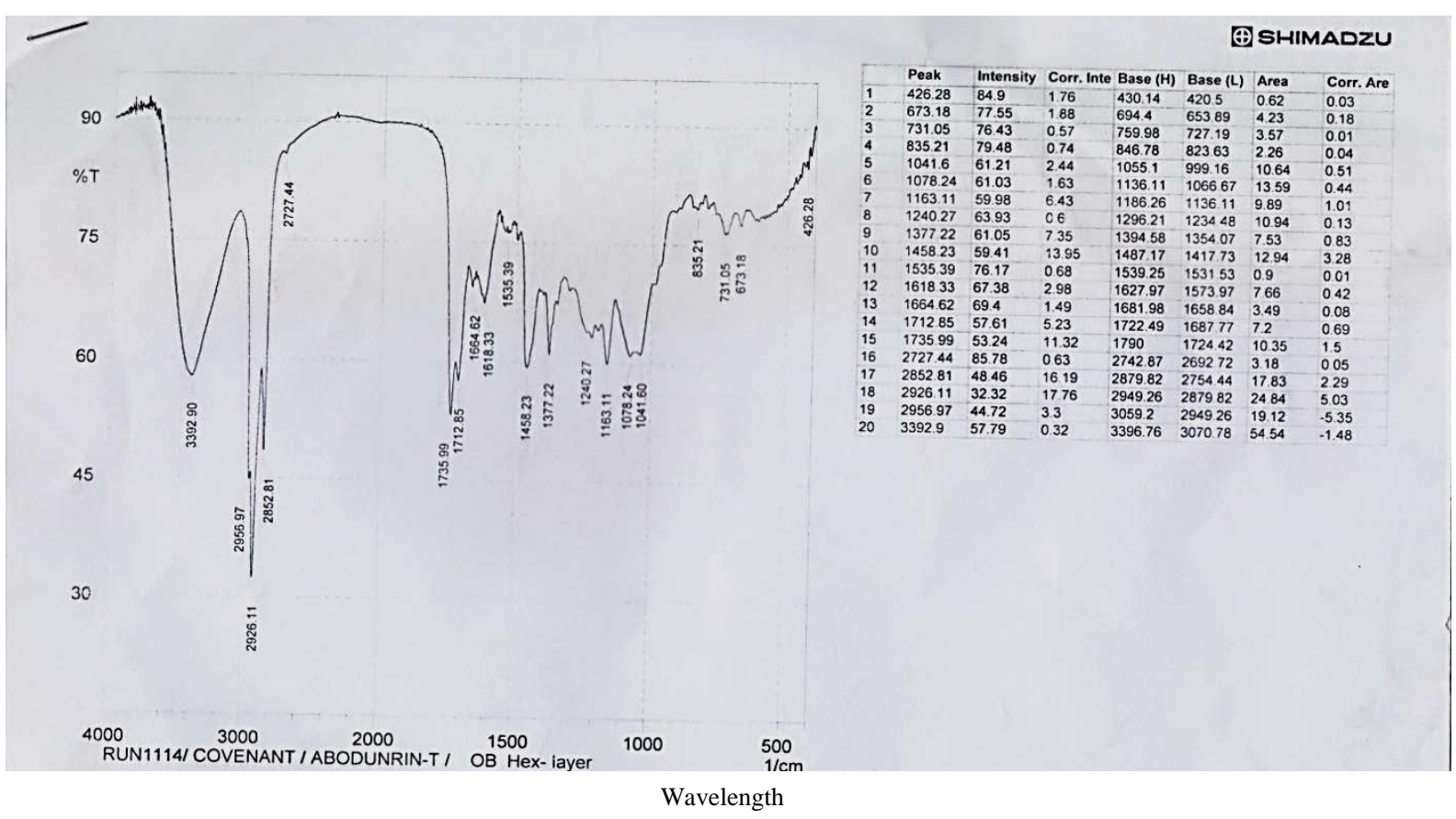

Figure 2. FTIR image of hexane faction of P. macrophylla leaf dye.

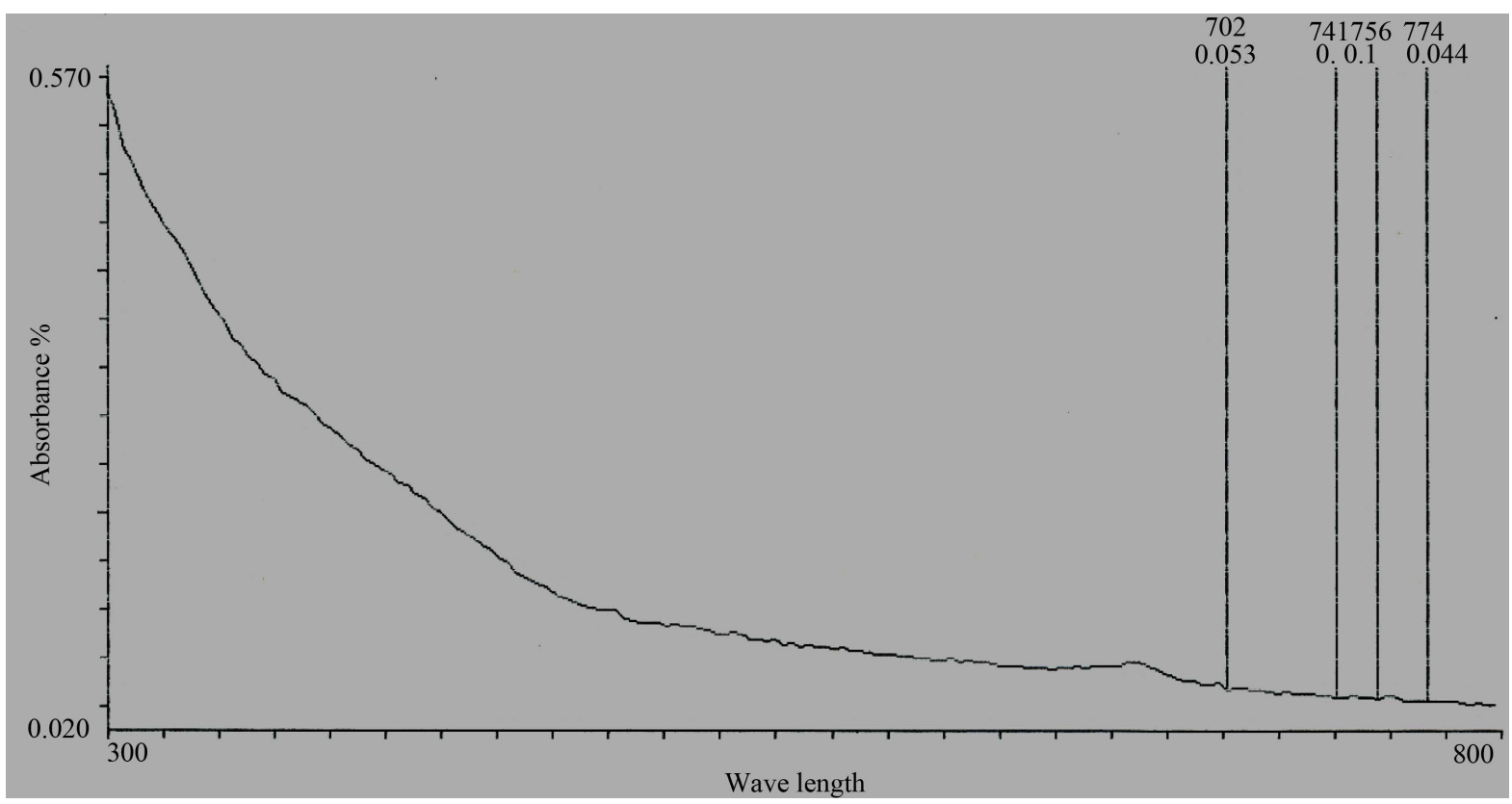

Figure 3. UV/Vis of P. macrophylla leaf dye without a sensitizer.

$\mathrm{nm}$ for $\mathrm{pH}$ 2.25, and $\mathrm{pH} 2.58,312 \mathrm{~nm}$ for $\mathrm{pH} 1.78$ and, $303 \mathrm{~nm}$ at $\mathrm{pH} 2.16$ in range of short wavelength. The dye extracts at $\mathrm{pH} 2.25$ and 2.58 have similar absorption intensity in long wavelength range. The highest intensity occurs at pH2.16 with a value of 2.936, which is higher than 2.880 at $220 \mathrm{~nm}$ for $\mathrm{pH} 5.20$ at short wavelength range (Figure 3). The lowest absorption intensity in long wavelength is observed for dye at $\mathrm{pH} 2.16$, indicating a degradation of the $M$. indica L. dye in strong acidic medium [18], at higher temperatures.

Dye extract at $\mathrm{pH}$ of 2.58 shows a broad absorption peak in the $303-400 \mathrm{~nm}$ range due to $\pi-\pi^{*}$ transitions due to the $\mathrm{O}-\mathrm{H}$ phenolic bond [20], which has a high concentration with a specific absorbance peak of 3392.90 $\mathrm{nm}$ (Figure 4) and broad appearance. 426 - $731 \mathrm{~nm}$ indicates the presence of chloroalkanes whose appearance is 
Table 2. FTIR analysis of compounds in P. macrophylla's leaf extract.

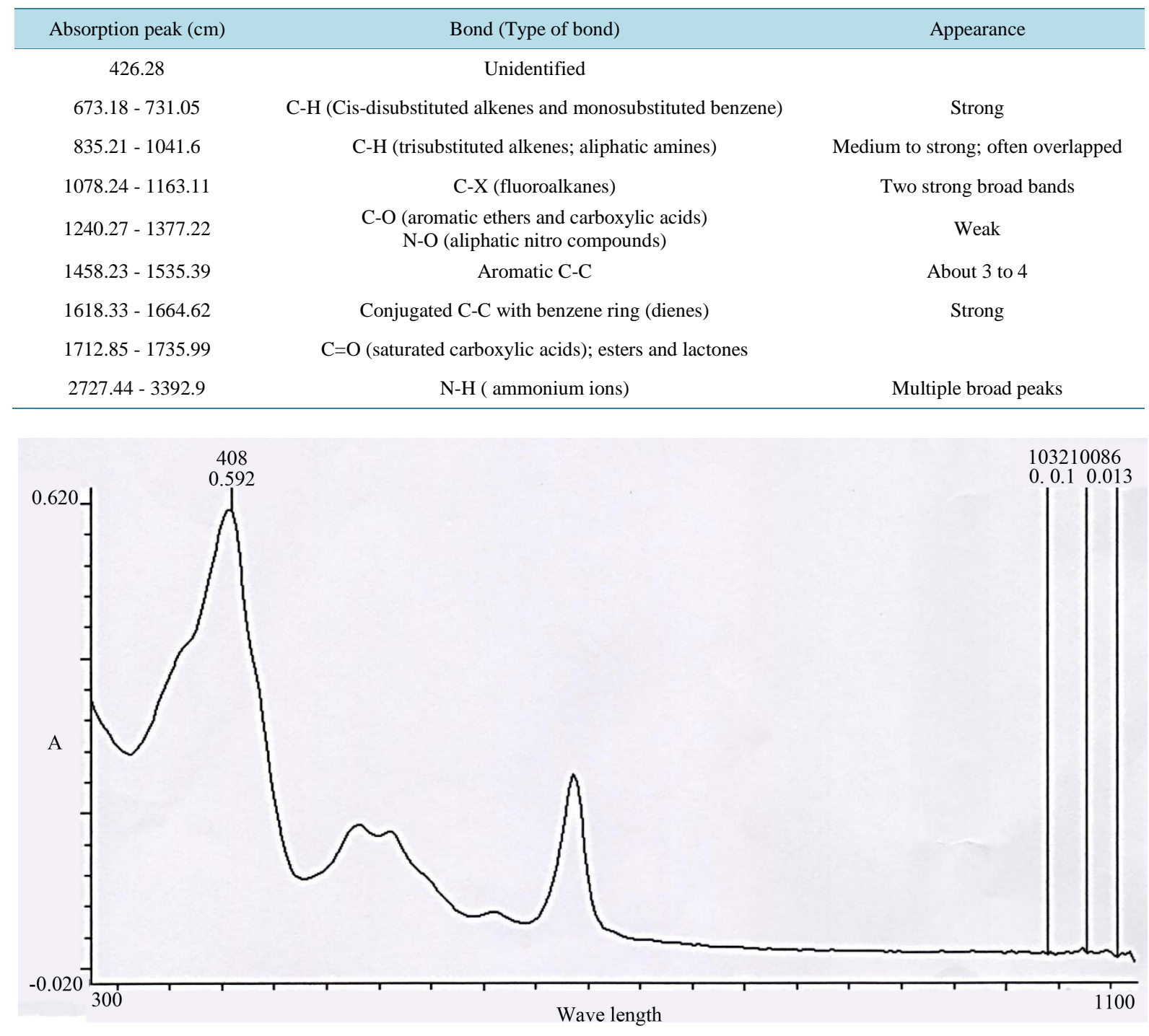

Figure 4. UV/Vis spectrograph of $P$. macrophylla leaf dye with KI electrolyte.

medium. $835.21 \mathrm{~nm}$ indicates the presence of the C-H bond, trisubstituted alkenes whose appearance is strong. 1041.6 - $1240.27 \mathrm{~nm}$ indicates presence of C-N bond, aliphatic amines which are often overlapped. $1377.22 \mathrm{~nm}$ indicates the presence of $\mathrm{C}-\mathrm{H}, 1458.23 \mathrm{~nm}$ indicates 3 or 4 weak to strong aromatic $\mathrm{C}=\mathrm{C}$ bond, $1535.39 \mathrm{~nm}$ indicates the presence of $\mathrm{N}-\mathrm{O}$ bond, aliphatic nitro compounds which are stronger in appearance. 1618.33 $1664.62 \mathrm{~nm}$ indicates the presence of $\mathrm{C}=\mathrm{N}$ with similar conjugation effects to $\mathrm{C}=\mathrm{O} .1712 .85-1735.99 \mathrm{~nm}$ indicates the presence of $\mathrm{C}=\mathrm{O}$ saturated carboxylic acids influenced by conjugation and ring size. $2727.44-2852.81$ $\mathrm{nm}$ indicates the presence of C-H bond, aldehydes of medium appearance. 2926.11 - 2956.97 nm indicates the presence of the methyl group (Figure 5 \& Figure 6), medium in appearance.

The combined J-V and P-V curves of the DSSCs at different pHs are shown in Figure 7. The open-circuit voltage $\mathrm{V}_{\text {oc }}$ of 0.38 is obtained for $\mathrm{pH} 2.58$ while at a $\mathrm{pH}$ of 2.25, and 2.16 the $\mathrm{V}_{\text {oc }}$ is 0.50 ; the least value is 0.13 when the $\mathrm{pH}$ is 1.78 . The dye with $\mathrm{pH} 2.58$ has the highest $\mathrm{J}_{\mathrm{sc}}$ of $1.30 \mathrm{~mA} / \mathrm{cm}^{2}$ and fill factor of 0.8 .

The temperature increase reduced the $\mathrm{J}_{\mathrm{sc}}$ of the dye at 2.16, the band gap is smaller as more electrons are excited and have high kinetic energy, and it also has the lowest fill factor, the resulting lupeol degradation in very strong acidic environment [18] causes poor harvesting of solar energy by the dye when injected on the $\mathrm{TiO}_{2}$ [21]. The photoelectric parameters are shown on Table 3 . Although $\mathrm{J}_{\mathrm{sc}}$ of $20.5 \mathrm{~mA} / \mathrm{cm}^{2}$ and $\mathrm{V}_{\text {ос }}$ of $0.72 \mathrm{~V}$ are ob- 


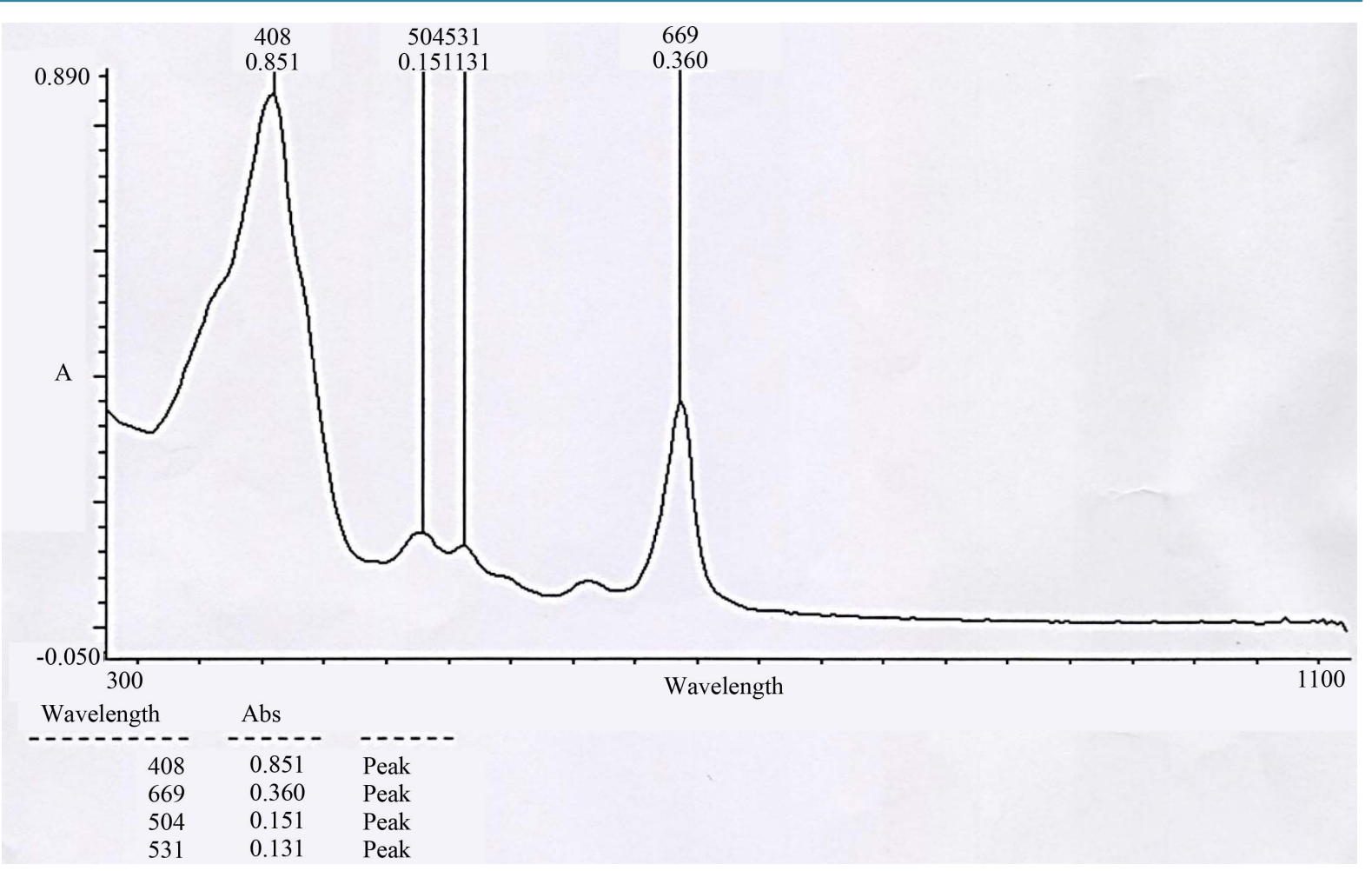

Figure 5. UV/V is Spectrograph of P. macrophylla leaf dye with $\mathrm{KBr}$ electrolyte.

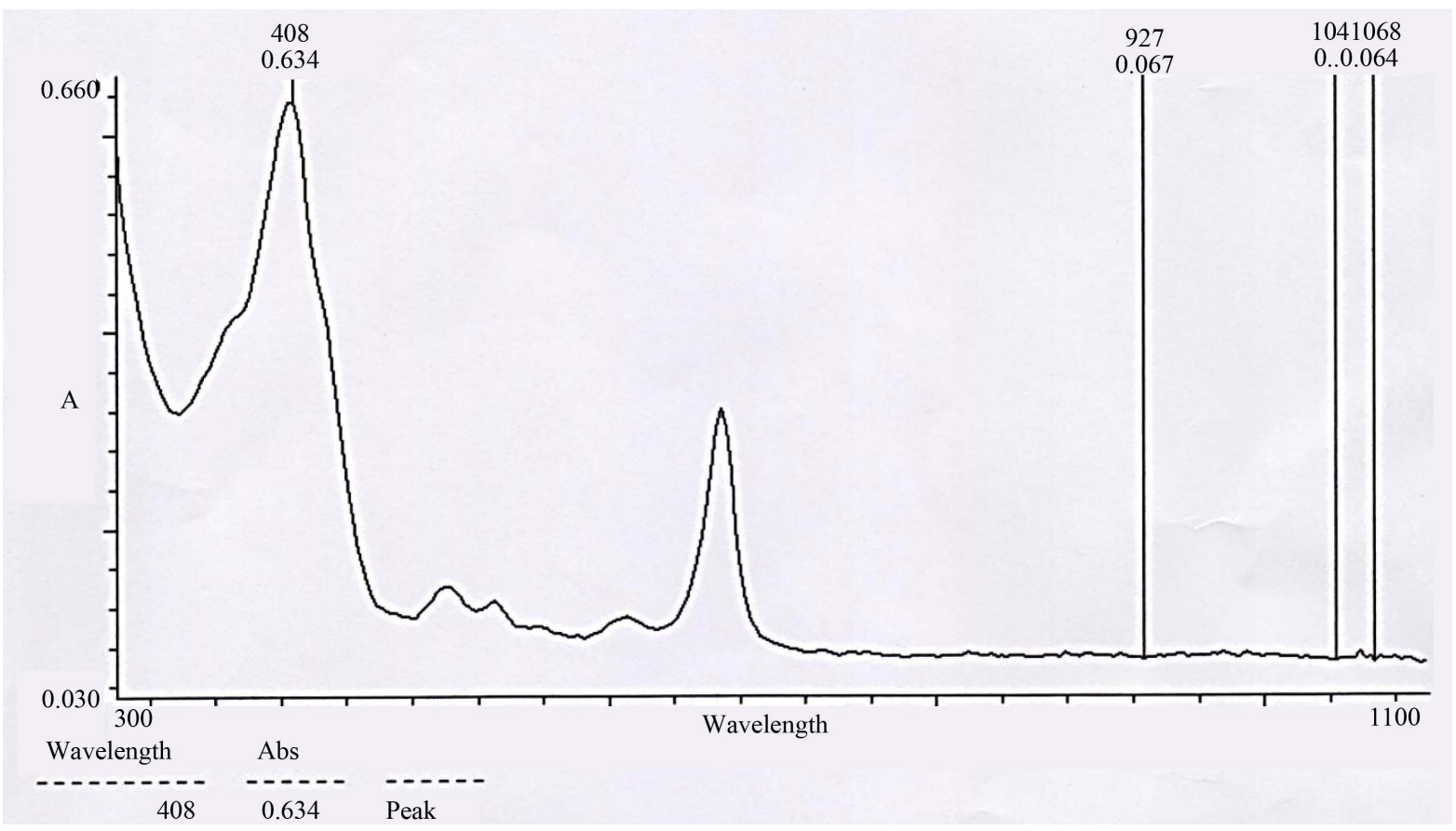

Figure 6. UV/V is Spectrograph of P. macrophylla leaf dye with $\mathrm{HgCl}_{2}$ electrolyte.

served under AM 1.5 [19] from the black dye, it is regarded as superior to all charge-transfer sensitizers. The $\mathrm{J}_{\mathrm{sc}}$ $1.30 \mathrm{~mA} / \mathrm{cm}^{2}$ at dye sensitizer $\mathrm{pH} 2.58$ is promising.

The Scanning Electron Microscope micrograph (Figure 8) of the $M$. indica L. shows the thickness of $M$. indica L. film. The M. indica L. film has a thickness of $9 \mu \mathrm{m}$ and a mean particle size of $20 \mathrm{~nm}$. The parallel veins 


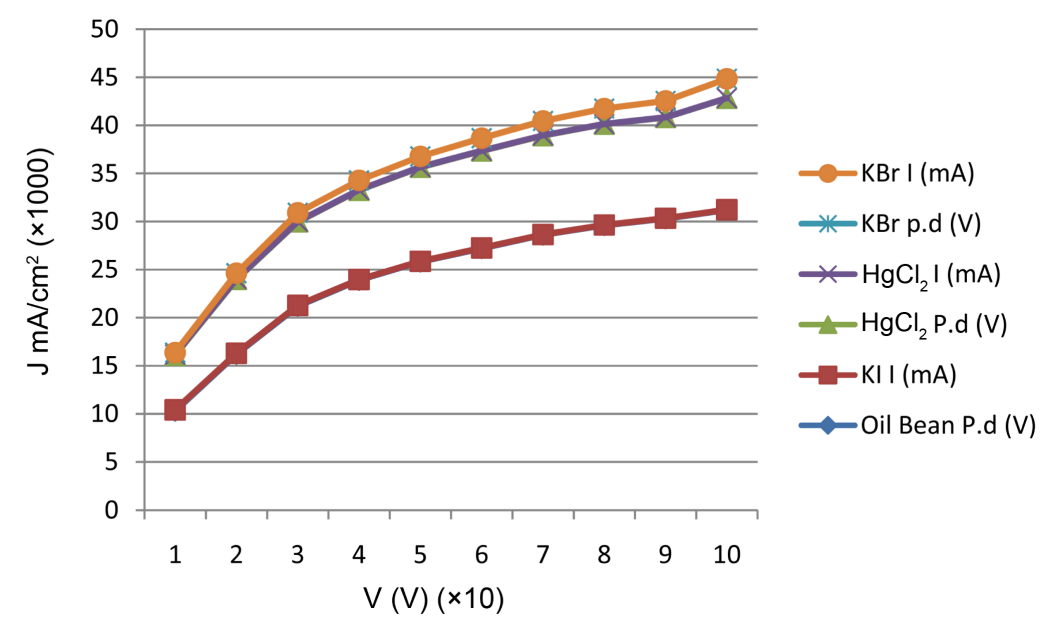

Figure 7. J-V characteristics of DSSCs with $\mathrm{KI}, \mathrm{KBr}$ and $\mathrm{HgCl}_{2}$ dye sensitizers with $P$. macrophylla extracts dye.

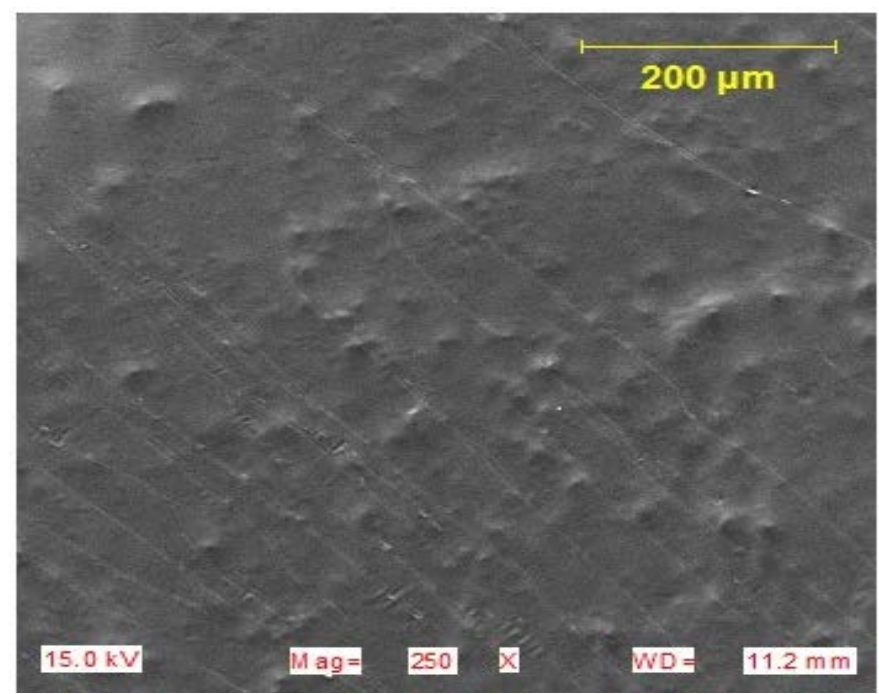

Figure 8. SEM micrograph of $M$. indica L.

Table 3. Characteristics of P. macrophylla dye-sensitized solar cells.

\begin{tabular}{ccccc}
\hline Dye-sensitizer & $\mathrm{J}_{\mathrm{sc}}\left(\mathrm{mA} / \mathrm{cm}^{-2}\right)$ & $\mathrm{V}_{\mathrm{oc}}(\mathrm{mV})$ & $\mathrm{FF}$ & \\
\hline $\mathrm{KI}$ & 0.20 & 0.032 & 0.48 & 0.21 \\
$\mathrm{KBr}$ & 0.16 & 0.045 & 0.28 & 0.36 \\
$\mathrm{HgCl}_{2}$ & 0.12 & 0.043 & 0.23 & 0.43 \\
\hline
\end{tabular}

of the leaf is distinctly outlined in the chromophores of M. indica L.

\section{Conclusion}

Lupeol's crude extracts of $M$. indica L. were used as natural dye sensitizers for DSSCs for different $\mathrm{pH}$ values. The DSSC at pH 2.16 had the least parameter values due to degradation of lupeol at increased temperatures and strong acidic environment resulting in the leaching of the adsorbed dye from the $\mathrm{TiO}_{2}$ surface. The dye sensitizer for DSSC at $\mathrm{pH} 2.58$ recorded the highest $\mathrm{J}_{\mathrm{sc}}$ of $1.3 \mathrm{~mA} / \mathrm{cm}^{2}$, a fill factor of 0.46 , and highest $\mathrm{p}_{\max }$ of 0.5 $\mathrm{mW} / \mathrm{cm}^{2}$. The low absorption of lupeol onto the titania surface at high $\mathrm{pH}$ led to decreased photochemical parameter of the cell at $\mathrm{pH}$ 2.16. These values are significantly less than that of black dye which is greater than all 
other charge-transfer sensitizers based on its performance under $1.5 \mathrm{AM}$ at the moment, with a confirmed $\mathrm{J}_{\mathrm{sc}}$ value of $20.5 \mathrm{~mA} / \mathrm{cm}^{2}$ and a $\mathrm{V}_{\text {oc }}$ of $0.72 \mathrm{~V}$ [19]. However, lupeol natural extract of M. indica L. represents an environmentally friendly, non-toxic, relatively cheap and available energy source, in dye sensitized solar cells.

\section{Acknowledgements}

This study was carried out with the Shimadzu FTIR equipment of the Chemical Science Department, Redeemers University, Ede. The SEM Aspex 3020 series of the Instrumentation Laboratory, Kwara State University, was used for this research. The UV/Vis spectrophotometer Genesys $10 \mathrm{UV} / \mathrm{visible}$ scanning of Wine light RC, 229,847 Analytical Sytems limited, USA of the Covenant University Central Instrumentation laboratory was used in the analysis of the UV/Vis spectral analysis.

\section{References}

[1] O’Reagan, B. and Grätzel, M. (1991) A Low Cost High-Efficiency Solar Cell Based on Dye-Sensitized Colloidal TiO 2 Films. Nature, 353, 737-740. http://dx.doi.org/10.1038/353737a0

[2] Grätzel, M. (2004) Conversion of Sunlight to Electric Power by Nanocrystalline Dye Sensitized Solar Cells. Journal of Photochemistry and Photobiology A: Chemistry, 164, 3-14. http://dx.doi.org/10.1016/j.jphotochem.2004.02.023

[3] Zhang, D., Lanier, S.M., Downing, J.A., Avent, J.L., Lum, J. and McHale, J.L. (2011) Betalain, Pigments for DyeSensitized Solar Cells. Journal of Photochemistry and Photobiology A: Chemistry, 219, 188-194.

[4] Chang, H., Wu, H.M., Chen, T.L., Huang, K.D., Jwo, C.S. and Lo, Y.J. (2010) Dye-Sensitized Solar Cell Using Natural Dyes Extracted from Spinach and Ipomea. Journal of Alloys and Compounds, 495, 606-610. http://dx.doi.org/10.1016/j.jallcom.2009.10.057

[5] Dai, Q. and Rabani, J. (2002) Photosensitization of Nanocrystalline $\mathrm{TiO}_{2}$ Films by Anthocyanin Dyes. Journal of Photochemistry and Photobiology A: Chemistry, 148, 17-24. http://dx.doi.org/10.1016/S1010-6030(02)00073-4

[6] Calogero, G., Di Marco, G., Cazzanti, S., Caramori, S., Argazzi, R., Di Carlo, A. and Alberto Bignozzi, C. (2010) Efficient Dye-Sensitized Solar Cells Using Red Turnip and Purple Wild Sicilian Prickly Pear Fruits. International Journal of Molecular Sciences, 11, 254-267. http://dx.doi.org/10.3390/ijms11010254

[7] Bisquert, J., García-Cañadas, J., Mors-Seró, I. and Palo-Mares, E. (2003) Comparative Analysis of Photovoltaic Principles Governing Dye-Sensitized Solar Cells and p-n Junctions. Proceedings of the SPIE, San Diego, 49-59.

[8] Nazeeruddin, M.K., Pechy, P., Renouard, T., Zakeeruddin, S.M., Humphry-Baker, R., Comte, P., Liska, P., Cevey, L., Costa, E., Shklover, V., Spiccia, L., Deacon, G.B., Bignozzi, C.A. and Grätzel, M. (2001) Engineering of Efficient Panchromatic Sensitizers for Nanocrystalline $\mathrm{TiO}_{2}$-Based Solar Cells. Journal of the American Chemical Society, 8, 1613-1624.

[9] Hara, K., Dan-Oh, Y., Kasada, C. and Arakawa, H. (2004) Effects of Additives on the Photovoltaic Performance of Coumarin-Dye-Sensitized Nanocrystalline $\mathrm{TiO}_{2}$ Solar Cells. Langmuir, 10, 4205-4210. http://dx.doi.org/10.1021/la0357615

[10] Ito, S., Zakeeruddin, S.M., Humphry-Baker, R., Liska, P., Charvet, R., Comte, P., Nazeeruddin, Md.K., Pechy, P., Takata, M., Miura, H., Uchida, S. and Grätzel, M. (2006) High Efficiency Organic-Dye-Sensitized Solar Cells Controlled by Nanocrystalline $\mathrm{TiO}_{2}$ Electrode Thickness. Advanced Materials, 18, 1202-1205. http://dx.doi.org/10.1002/adma.200502540

[11] Kim, S., Lee, J.K., Kang, S.O., Ko, J.J., Yum, J.H., Fantacci, S., De Angelis, F., Di Censo, D., Nazeeruddin, M.K. and Grätzel, M. (2006) Molecular Engineering of Organic Sensitizers for Solar Cell Applications. Journal of the American Chemical Society, 128, 16701-16707. http://dx.doi.org/10.1021/ja066376f

[12] Wongcharee, K., Meeyoo, V. and Chavadej, S. (2007) Dye-Sensitized Solar Cell Using Natural Dyes Extracted from Rosella and Blue Pea Flowers. Solar Energy Material Solar Cells, 91, 566-571. http://dx.doi.org/10.1016/j.solmat.2006.11.005

[13] Tennakone, K., Kumara, G.R.R.A., Kumarasinghe, A.R., Sirimanne, P.M. and Wijayantha, K.G.U. (1996) Efficient Photosensitization of Nanocrystalline $\mathrm{TiO}_{2}$ Films by Tannins and Related Phenolic Substances. Journal of Photochemistry and Photobiology A: Chemistry, 94, 217-220. http://dx.doi.org/10.1016/1010-6030(95)04222-9

[14] Kushwaha, R., Srivastava, P. and Bahadur, L. (2013) Natural Pigments from Plants Used as Sensitizers for TiO $\mathrm{Tased}_{2}$ Dye-Sensitized Solar Cells. Journal of Energy, 2013, Article ID: 654953.

[15] Anyaneyulu, V. and Radhika, P. (2000) The Triterpenoids and Steroids from Mangifera indica Linn. Indian Journal of Chemistry, 39B, 883-893.

[16] Shivanghi, G. (2015) Journal of Pharmacy and Bioallied Sciences, 7, 1-85. 
[17] Sze, S.M. and Lee, M. (1969) Physics of Semiconductor Devices. Wiley, New York.

[18] Pedreno, M.A. and Escribano, J. (2001) Correlation between Antiradical Activity and Stability of Betanine from Beta vulgaris L. Roots under Different $\mathrm{pH}$, Temperature and Light Conditions. Journal of the Science of Food and Agriculture, 81, 627-631. http://dx.doi.org/10.1002/jsfa.851

[19] Qin, Y. and Penq, Q. (2012) Ruthenium Sensitizers and Their Applications in Dye-Sensitized Solar Cells. International Journal of Photoenergy, 2012, 1-21. http://dx.doi.org/10.1155/2012/291579

[20] Peter, L. (2011) Infrared and Raman Characteristic Group Frequencies: Tables and Charts. 18.

[21] Hernández-Martínez, A.R., Vargas, S., Estevez, M. and Rodríguez, R. (2010) Dye-Sensitized Solar Cells from Extracted Bracts Bougainvillea betalain Pigments. Proceedings of the 1st International Congress on Instrumentation and Applied Sciences, Cancun, Q. R., 26-29 October 2010. 